OPEN ACCESS

Edited by:

Weina Meng,

Stevens Institute of Technology,

United States

Reviewed by:

E. Chen,

Chalmers University of Technology,

Sweden

Xinmei Hou,

University of Science and Technology

Beijing, China

Mohamed Amin,

Ain Sham University, Egyp

*Correspondence: Wu Zhiqiang wuzhq2@cnooc.com.cn

Cheng Xiaowei

chengxw@swpu.edu.cn

Specialty section:

This article was submitted to

Structural Materials,

a section of the journal

Frontiers in Materials

Received: 02 November 2021

Accepted: 13 December 2021

Published: 05 January 2022

Citation:

Zhiqiang W, Hengjie L, Xiong $Q$, Guangai W, Xuesong X, Xiaowei C and Xiucheng $N$ (2022) Improvement of Calcium Aluminate Cement Containing Blast Furnace Slag at $50^{\circ} \mathrm{C}$ and $315^{\circ} \mathrm{C}$.

Front. Mater. 8:807596.

doi: 10.3389/fmats.2021.807596

\section{Improvement of Calcium Aluminate Cement Containing Blast Furnace Slag at $50^{\circ} \mathrm{C}$ and $315^{\circ} \mathrm{C}$}

\author{
Wu Zhiqiang ${ }^{1 *}$, Liu Hengjie ${ }^{2}$, Qu Xiong ${ }^{3}$, Wu Guangai ${ }^{1}$, Xing Xuesong ${ }^{1}$, Cheng Xiaowei ${ }^{4 *}$ and \\ Ni Xiucheng ${ }^{4}$
}

${ }^{1}$ CNOOC Research Institute Co., Ltd., Beijing, China, ${ }^{2}$ PetroChina Southwest Oil and Gas Field Company, Chengdu, China, ${ }^{3}$ CNPC Chuanqing Drilling Engineering Company Limited, Chengdu, China, ${ }^{4}$ School of New Energy and Materials, Southwest Petroleum University, Chengdu, China

During the thermal recovery of heavy oil thermal recovery wells, improving the mechanical properties and integrity of the cement ring is of great significance for the safe and efficient exploitation of heavy oil resources. This paper studies the relative properties of calcium aluminate cement and three kinds of slags under the conditions of $50^{\circ} \mathrm{C} \times 1.01 \mathrm{MPa}$ and $315^{\circ} \mathrm{C} \times 20.7 \mathrm{MPa}$. CAC-slag composite material performance was evaluated using the cement paste compressive strength and permeability tests to study the physical properties of CAC with blast furnace slag. X-ray diffraction analysis, scanning electron microscopy (SEM), and thermal analysis (DSC/TG) were carried out to investigate the mineralogical composition of CAC with blast furnace slag. Results show that adding blast furnace slag did not affect the performance of cement slurry. Moreover, $\mathrm{C}_{2} \mathrm{ASH}_{8}$ curing occurred at low temperature, the microstructure of CAC paste was compact, and the permeability resistance was improved, thus improving the low-temperature properties of neat CAC. When cured at a high temperature, the CAC paste was mainly hydrated with $\mathrm{C}_{3} \mathrm{ASH}_{4}$ and $\mathrm{AlO}(\mathrm{OH})$, which had a well-developed crystal structure. Adding blast furnace slag can improve the CAC resistance to high temperature.

Keywords: thermal recovery, blast furnace slag, CAC, high temperature, mechanical properties, phase and microstructure

\section{INTRODUCTION}

Steam flooding is a thermal-recovery technique of heavy oil exploitation. During the process of thermal recovery, a cement sheath is used as a supporting casing and isolates the cementing intervals that can withstand steam environments of up to $300-350^{\circ} \mathrm{C}$. This is a challenge for cementing materials for heavy oil thermal-recovery wells (Nabih and Chalaturnyk, 2014; Pang et al., 2018; Chai et al., 2022; Ding et al., 2021). However, silicate cement added to sand is often used at high temperatures in hot and humid environments for long periods of heavy oil thermal recovery; the compressive strength declines sharply, causing zonal isolation invalidation and shortening the working life of the oil well (Walker, 1962; Salehpour et al., 2014). Calcium aluminate cement (CAC) is used as refractory material and has characteristics of high strength, rapid hardening, and resistance to high temperatures over a long period of time (Kar et al., 2012; Idrees et al., 2021; Roig-Flores et al., 2021; Abolhasani et al., 2021). Thus, CAC

Abbreviations: $\mathrm{A}, \mathrm{Al}_{2} \mathrm{O}_{3} ; \mathrm{C}, \mathrm{CaO} ; \mathrm{H}, \mathrm{H}_{2} \mathrm{O} ; \mathrm{S}, \mathrm{SiO}_{2}$ 


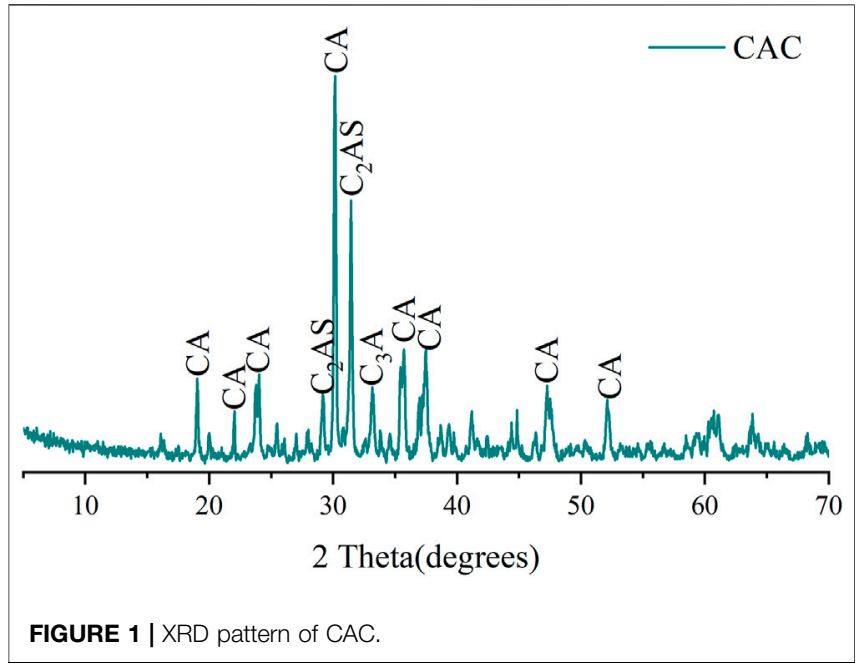

has potential use in heavy oil thermal recovery well cementing. CAC has previously been used as a building or refractory material in simpler environments compared with thermal recovery. The curing temperature of the CAC hydration products and its structure are vital roles. Recent research on CAC have reported (Goberis and Antonovich, 2004; Ukrainczyk and Matusinović, 2010; Kirca et al., 2013; Pacewska et al., 2013) that temperatures used are mostly in the range of $20-70^{\circ} \mathrm{C}$ and few experiments have been performed on $\mathrm{CAC}$ paste curing at $300-350^{\circ} \mathrm{C}$. In recent years, research on CAC has mostly focused on hydration characteristics and fracture toughness, using slag as an auxiliary cementing material to improve the mechanical performance of CAC (Amin et al., 2012; Cheng et al., 2019), and often perform collaborative analysis with concrete (Wang et al., 2021a; Wang et al., 2021b; Huang et al., 2021). Therefore, research on the resistance performance of CAC in hot and humid environments at high temperatures has great significance.

Alternately, $\mathrm{CAC}$ is sensitive when cured at low temperatures. $\mathrm{CAH}_{10}$ is mainly generated when cured below $20^{\circ} \mathrm{C}, \mathrm{C}_{2} \mathrm{AH}_{8}, \mathrm{AH}_{3}$ are generated when cured at $30^{\circ} \mathrm{C}$, and $\mathrm{C}_{3} \mathrm{AH}_{6}$ and $\mathrm{AH}_{3}$ are mainly generated when cured at more than $45^{\circ} \mathrm{C}$. The hydration reaction is as follows (Sakai et al., 2010; Mostafa et al., 2012):

$$
\begin{gathered}
2 \mathrm{CA}_{2}+26 \mathrm{H} \rightarrow 2 \mathrm{CAH}_{10}+2 \mathrm{AH}_{3} \\
2 \mathrm{CA}+11 \mathrm{H} \rightarrow \mathrm{C}_{2} \mathrm{AH}_{8}+\mathrm{AH}_{3} \\
3 \mathrm{CA}+12 \mathrm{H} \rightarrow \mathrm{C}_{3} \mathrm{AH}_{6}+2 \mathrm{AH}_{3}
\end{gathered}
$$

The hydration products $\mathrm{CAH}_{10}$ and $\mathrm{C}_{2} \mathrm{AH}_{8}$ are in the metastable phase, which occurs during the conversion reaction to a product that is more stable. The reaction for cubic $\mathrm{C}_{3} \mathrm{AH}_{6}$ compounds at high temperature curing is as follows:

$$
\begin{gathered}
3 \mathrm{CAH}_{10} \rightarrow \mathrm{C}_{3} \mathrm{AH}_{6}+2 \mathrm{AH}_{3}+18 \mathrm{H} \\
2 \mathrm{CAH}_{10} \rightarrow \mathrm{C}_{2} \mathrm{AH}_{8}+\mathrm{AH}_{3}+9 \mathrm{H} \\
3 \mathrm{C}_{2} \mathrm{AH}_{8} \rightarrow 2 \mathrm{C}_{3} \mathrm{AH}_{6}+\mathrm{AH}_{3}+9 \mathrm{H}
\end{gathered}
$$

Based on these reaction results, the strength of CAC at low temperature is unstable, especially when cured at $50-60^{\circ} \mathrm{C}$. This unstable strength greatly limits the use of CAC in cementing engineering applications. According to previous reports (Heikal et al., 2005), adding blast furnace slag to CAC can improve the mechanical properties of CAC when cured at low temperature.

This paper aims to explore the influence of the three blast furnace slags on the high temperature resistance of CAC for heavy oil thermal recovery, the physical and microscopic properties of $\mathrm{CAC}$ change during the simulated processes of cementing at $50^{\circ} \mathrm{C} \times 1.01 \mathrm{MPa}$ and steam drive oil at $315^{\circ} \mathrm{C} \times$ $20.7 \mathrm{MPa}$.

\section{EXPERIMENTAL}

\section{Materials}

CAC was produced by the Zhengzhou Xinxing special cement plant, China. The XRD pattern of CAC is shown in Figure 1. Three types of blast furnace slag: FSa, FSb, and FSc are all from Chengdu Hongsheng Technology Co., Ltd., China (Table 1). A filtrate reducer G33S (AMPS/AM/AA terpolymer), a retarder SR (lignin sulfonate and boric acid salt mixture), and tap water (waterworks Chengdu) were also used.

\section{Preparation of Samples}

The preparation procedure of the cement slurry is in accordance with the API standard. The neat cement slurry consisted of CAC, $1.5 \%$ (relative to the cement weight) filtrate reducer G33S, $0.45 \%$ retarder SR, and tap water, mark as Ms. The cement slurry with furnace blast furnace slag consisted of CAC with $30 \% \mathrm{FSa}$, FSb, or FSc, $2 \%$ filtrate reducer G33S, $0.6 \%$ retarder SR, and tap water, marked as $\mathrm{Ma}, \mathrm{Mb}$, and $\mathrm{Mc}$ respectively. The density of both cement slurries was $1.85 \mathrm{~g} / \mathrm{cm}^{3}$. Four CAC formulas were designated with the codes $\mathrm{Ms}$, Ma, Mb, and Mc. The experimental formula is shown in Table 2.

The cement slurry was poured into $50.8 \times 50.8 \times 50.8 \mathrm{~mm}^{3}$ cubic molds and cured in a bath (HH-8; Jintan City Jerry Electric Appliance Co., Ltd., China) at $50^{\circ} \mathrm{C}$ for 7 days to simulate the thermal recovery process. The cured samples were then moved to a water-cycling, high-temperature, and high-pressure curing reactor (OWC-9390Y; Shenyang Institute of Aviation Industry Application Technology Research Institute, China) and cured at

TABLE 1 | Chemical composition and percentage content of slag and CAC.

\begin{tabular}{lcccc} 
Materials & CAC & FSa & FSb & FSc \\
\hline Specific gravity & 3.10 & 2.70 & 2.95 & 2.70 \\
Average specific area $\left(\mathrm{m}^{2} / \mathrm{g}\right)$ & 0.36 & 1.36 & 1.503 & 1.01 \\
$\mathrm{CaO}(\%)$ & 37.85 & 32.7 & 50.8 & 38.2 \\
$\mathrm{SiO}_{2}(\%)$ & 4.94 & 33.5 & 27.3 & 31.8 \\
$\mathrm{Al}_{2} \mathrm{O}_{3}(\%)$ & 55.29 & 16.6 & 6.93 & 14.0 \\
$\mathrm{MgO}(\%)$ & - & 6.25 & 3.81 & 9.60 \\
$\mathrm{Fe}_{2} \mathrm{O}_{3}(\%)$ & 1.68 & 2.87 & 3.58 & 1.24 \\
$\mathrm{SO}_{3}(\%)$ & - & 2.77 & 2.70 & 1.90 \\
$\mathrm{TiO}_{2}(\%)$ & - & 2.60 & 2.31 & 1.26 \\
$\mathrm{~K}_{2} \mathrm{O}(\%)$ & - & 1.09 & 0.755 & 0.581 \\
$\mathrm{MnO}_{2}(\%)$ & - & 0.526 & 0.320 & 0.68 \\
$\mathrm{Na}_{2} \mathrm{O}(\%)$ & - & 0.409 & 0.359 & 0.322 \\
Others $(\%)$ & 0.24 & 0.685 & 1.136 & 0.417 \\
& & & &
\end{tabular}


TABLE 2 | Cement slurry formula.

\begin{tabular}{|c|c|c|c|c|c|c|c|}
\hline \multirow[t]{2}{*}{ Id } & \multirow[t]{2}{*}{$\mathrm{CAC} / \%$} & \multicolumn{2}{|c|}{ Slag } & \multirow[t]{2}{*}{ G33S/\% } & \multirow[t]{2}{*}{ SR/\% } & \multirow[t]{2}{*}{ Water/\% } & \multirow[t]{2}{*}{ Density $/ \mathrm{g} / \mathrm{cm}^{3}$} \\
\hline & & Type & Amount/\% & & & & \\
\hline Ms & 100 & - & - & 1.5 & 0.45 & 44 & 1.85 \\
\hline $\mathrm{Ma}$ & 100 & $\mathrm{FSa}$ & 30 & 2 & 0.6 & 44 & 1.85 \\
\hline $\mathrm{Mb}$ & 100 & $\mathrm{FSb}$ & 30 & 2 & 0.6 & 44 & 1.85 \\
\hline $\mathrm{Mc}$ & 100 & FSc & 30 & 2 & 0.6 & 44 & 1.85 \\
\hline
\end{tabular}

TABLE 3 | Properties of the CAC slurry.

\begin{tabular}{|c|c|c|c|c|c|c|c|c|}
\hline \multirow[t]{2}{*}{ Formula } & \multirow[t]{2}{*}{ Density $\left(\mathrm{g} / \mathrm{cm}^{3}\right)$} & \multirow[t]{2}{*}{ Fluidit (cm) } & \multirow{2}{*}{$\begin{array}{c}\text { Free fluid } \\
\text { (\%) }\end{array}$} & \multirow{2}{*}{$\begin{array}{l}\text { API fluid } \\
\text { loss (ml) }\end{array}$} & \multirow{2}{*}{$\begin{array}{l}\text { 100Bc thickening } \\
\text { time (min) }\end{array}$} & \multicolumn{3}{|c|}{ Stability $(\triangle \rho s c / \%)$} \\
\hline & & & & & & Top & Middle & Bottom \\
\hline Ms & 1.85 & 26.5 & 0.5 & 50 & 143 & 99.9 & 100.0 & 100.1 \\
\hline $\mathrm{Mb}$ & 1.85 & 24 & 0.2 & 44 & 156 & 99.8 & 100.0 & 100.2 \\
\hline Mc & 1.85 & 25 & 0.2 & 35 & 152 & 100.0 & 100.0 & 100.0 \\
\hline
\end{tabular}

Note: The thickening time is tested under the conditions of a pressure of $45 \mathrm{MPa}$, a temperature of $50^{\circ} \mathrm{C}$, and a heating time of $30 \mathrm{~min}$.

$315^{\circ} \mathrm{C}$ and 20.7 MPa for 7 days. The cubic molds were maintained in a constant temperature water bath for low-temperature curing and completely immersed in high temperature thickened oil for high-temperature and high-pressure curing.

\section{Testing Methods}

The method for the slurry performance test is in accordance with the API standard. Density, fluidity, free fluid, API fluid loss, and thickening time at $100 \mathrm{Bc}$ were evaluated.

The compressive strength of cubic samples was determined using a testing machine (TA300; Beijing $\mathrm{Ha}$ Wisdom Technology Co., Ltd., China). Six samples were used to determine the compressive strengths at each specified age. The loading rate is $2000 \mathrm{~N} / \mathrm{s}$. Permeability was determined on cylindrical samples with a size of $\Phi$ $200 \mathrm{~mm} \times 500 \mathrm{~mm}$ by using a core permeability measuring instrument (DSK III; Changzhou Yiyong Technology Co., Ltd., China). The rock sample was dried at $60^{\circ} \mathrm{C}$ for 3 days, and the absolute permeability of the rock sample was measured by the gas method. The results were the arithmetic average of three specimens at the minimum. The hydration products of cement paste were determined by X-ray diffraction (XRD; DX-1000; Dandong Fangyuan Instrument Co., Ltd., China). Samples were prepared by grinding compressive specimens with the test step length at $0.08^{\circ}$, scan rate at $2^{\circ}$ per minute, and 2 -theta angle range of $5^{\circ}-70^{\circ}$, The voltage and current of the test equipment are $30 \mathrm{kV}$ and $20 \mathrm{~mA}$ respectively. The microstructure morphology of the cement paste was determined using an environmental scanning electron microscope (FEI Quanta450; USA) with a vacuum ion sputtering apparatus (LDM150D type; USA) that coats a layer of Au to all of the samples. The morphology of the cement was then observed through SEM. Resolution: high vacuum mode, $3.0 \mathrm{~nm}$ $(30 \mathrm{kV})$; Magnification: 5X-300000X; Accelerating voltage: $0.3-30 \mathrm{kV}$; Sample stage stroke $X=100 \mathrm{~mm}$ and above,

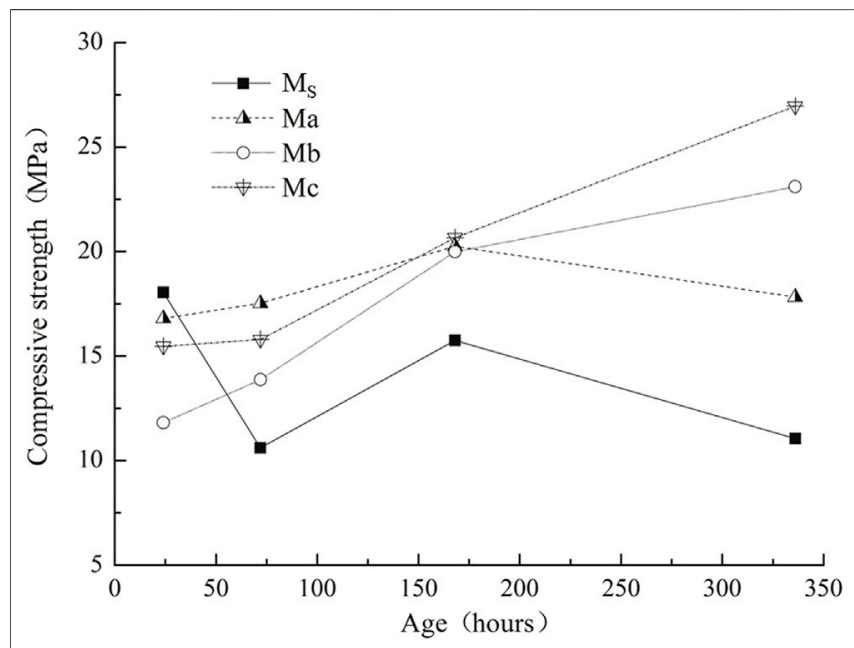

FIGURE 2 | Influence of admixture on early strength of aluminate cement stone $\left(50^{\circ} \mathrm{C}\right)$.

$Y=100 \mathrm{~mm}$ and above, $Z=100 \mathrm{~mm}$ and above; $T=$ $10^{\circ}-90^{\circ} ; R=360^{\circ}$. The cement was tested for heat absorption at $25-900^{\circ} \mathrm{C}$, with a heating rate of $10^{\circ} \mathrm{C} / \mathrm{min}$, sensitivity of $0.04 \mu \mathrm{w}$, and calorimeter precision of $0.1 \%$ in a thermal analyzer (TGA/SDTA85/; Mettler-Toledo, Switzerland). The reaction gas is air with a flow rate of $10 \mathrm{ml} / \mathrm{min}$; the shielding gas is nitrogen with a flow rate of $20 \mathrm{ml} / \mathrm{min}$.

\section{RESULTS AND DISCUSSION}

\section{Properties of the CAC Slurry}

Table 3 shows the fundamental properties of the CAC slurry. The CAC slurry had a density of $1.85 \mathrm{~g} / \mathrm{cm}^{3}$, good liquidity, and 
TABLE 4 | Influence of slag on the high temperature resistance of aluminate cement stone.

\begin{tabular}{|c|c|c|c|c|}
\hline \multirow[t]{2}{*}{ Formula } & \multicolumn{2}{|c|}{ Permeability (mD) } & \multicolumn{2}{|c|}{$\begin{array}{l}\text { Compressive } \\
\text { strength (MPa) }\end{array}$} \\
\hline & $50^{\circ} \mathrm{C}$ & $315^{\circ} \mathrm{C}$ & $50^{\circ} \mathrm{C}$ & $315^{\circ} \mathrm{C}$ \\
\hline Ms & 0.0498 & 0.0446 & 11.05 & 15.10 \\
\hline $\mathrm{Ma}$ & 0.0280 & 0.0344 & 17.82 & 16.56 \\
\hline $\mathrm{Mb}$ & 0.0200 & 0.0341 & 23.10 & 19.70 \\
\hline Mc & 0.0112 & 0.0338 & 26.96 & 25.49 \\
\hline
\end{tabular}

less free fluid. API fluid loss was within $50 \mathrm{ml}$ and was reduced when mixed with $30 \%$ furnace blast furnace slag. The thickening time of the $100 \mathrm{Bc}$ control was within $2-3 \mathrm{~h}$, which satisfies the Liaohe oilfield blocks $\mathrm{Q}$ cementing operation requirements in China.

\section{Mechanical Behavior \\ Early Compressive Strength}

This experiment demonstrated the early compressive strength of a CAC paste under low-temperature $\left(50^{\circ} \mathrm{C}\right)$ curing in a water bath, as shown in Figure 2. Under this curing condition, the pure aluminate cement compressive strength changed. Moreover, the intensity fluctuation was larger after only 1 day $(24 \mathrm{~h})$, and the strength was higher than that of the CAC paste mixed with blast furnace slag. Fentiman et al. (Fentiman et al., 2020) also found that, in the early days, the compressive strength of CAC paste with blast furnace slag is lower than that of pure CAC paste. Compared with pure CAC paste, the compressive strength of CAC paste mixed with blast furnace slag exhibited a larger increase and was relatively stable after 3 days $(72 \mathrm{~h})$, and the compressive strength gradually increased with curing time. The compressive strength increased because the hydration reaction produced $\mathrm{C}_{2} \mathrm{ASH}_{8}$ (also called stratlingite) instead of $\mathrm{C}_{3} \mathrm{AH}_{6}$ (Antonovič et al., 2013).

\section{High-Temperature Performance of CAC Paste With Blast Furnace Slag}

The permeability and compressive strength of CAC paste cured at $50^{\circ} \mathrm{C} \times 1.01 \mathrm{MPa}$ and $315^{\circ} \mathrm{C} \times 20.7 \mathrm{MPa}$ are shown in Table 4 The permeability of $\mathrm{Ms}$ is larger. However, the relative permeability of $\mathrm{Ma}, \mathrm{Mb}$, and $\mathrm{Mc}$ was improved substantially compared with Ms. This result indicates that the structure of CAC paste with blast furnace slag was denser and had increased compressive strength. In particular, the resistance of the permeability of $\mathrm{Mc}$ was higher than that of Ms by $77.5 \%$, and its compressive strength increased by $74.2 \%$ at $50^{\circ} \mathrm{C}$ curing. This is because the CAC with blast furnace slag hydration reaction produces stratlingite crystal and the pure CAC hydration reaction produces $\mathrm{C}_{3} \mathrm{AH}_{6}$. The volume of the $\mathrm{C}_{3} \mathrm{AH}_{6}$ crystal phase is smaller. Thus, the apparent porosity increases, thereby weakening permeability resistance and compressive strength (Tseng and Nian, 2004). The antipermeability property of the CAC paste was reduced by curing at high temperature. However, the anti-permeability of $\mathrm{Ma}, \mathrm{Mb}$, and $\mathrm{Mc}$ was still higher than that of $\mathrm{Ms}$ by at least $22.8 \%$, and the compressive strength of $\mathrm{Ma}, \mathrm{Mb}$, and $\mathrm{Mc}$ was higher than that of Ms by at least $9.7 \%$. This result indicates that the three types of blast furnace slag can improve the antipermeability and compressive strength properties of CAC paste at 50 and $315^{\circ} \mathrm{C}$.

\section{Hydration Products and Microstructure Testing XRD Analysis}

The hydrated phases formed by $\mathrm{Ms}, \mathrm{Ma}, \mathrm{Mb}$, and $\mathrm{Mc}$ were investigated using XRD. Figure 3A shows the XRD pattern of

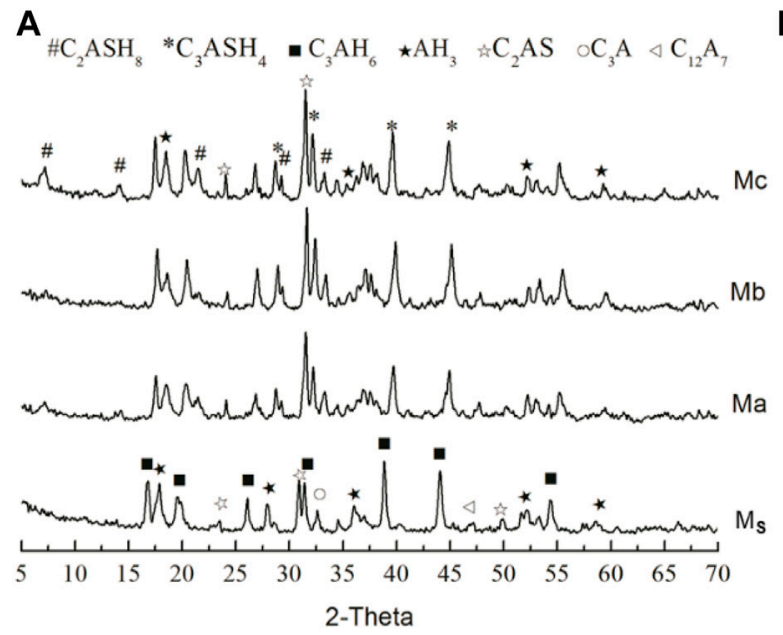

curing at low temperature

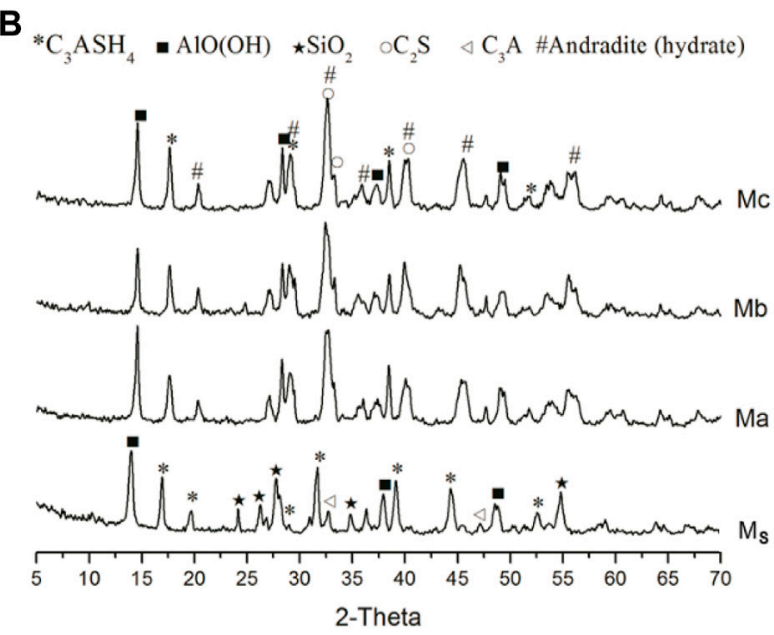

curing at high temperature

FIGURE $3 \mid$ XRD patterns of Ms, Ma, Mb, and Mc. (A) curing at low temperature. (B) curing at high temperature. 

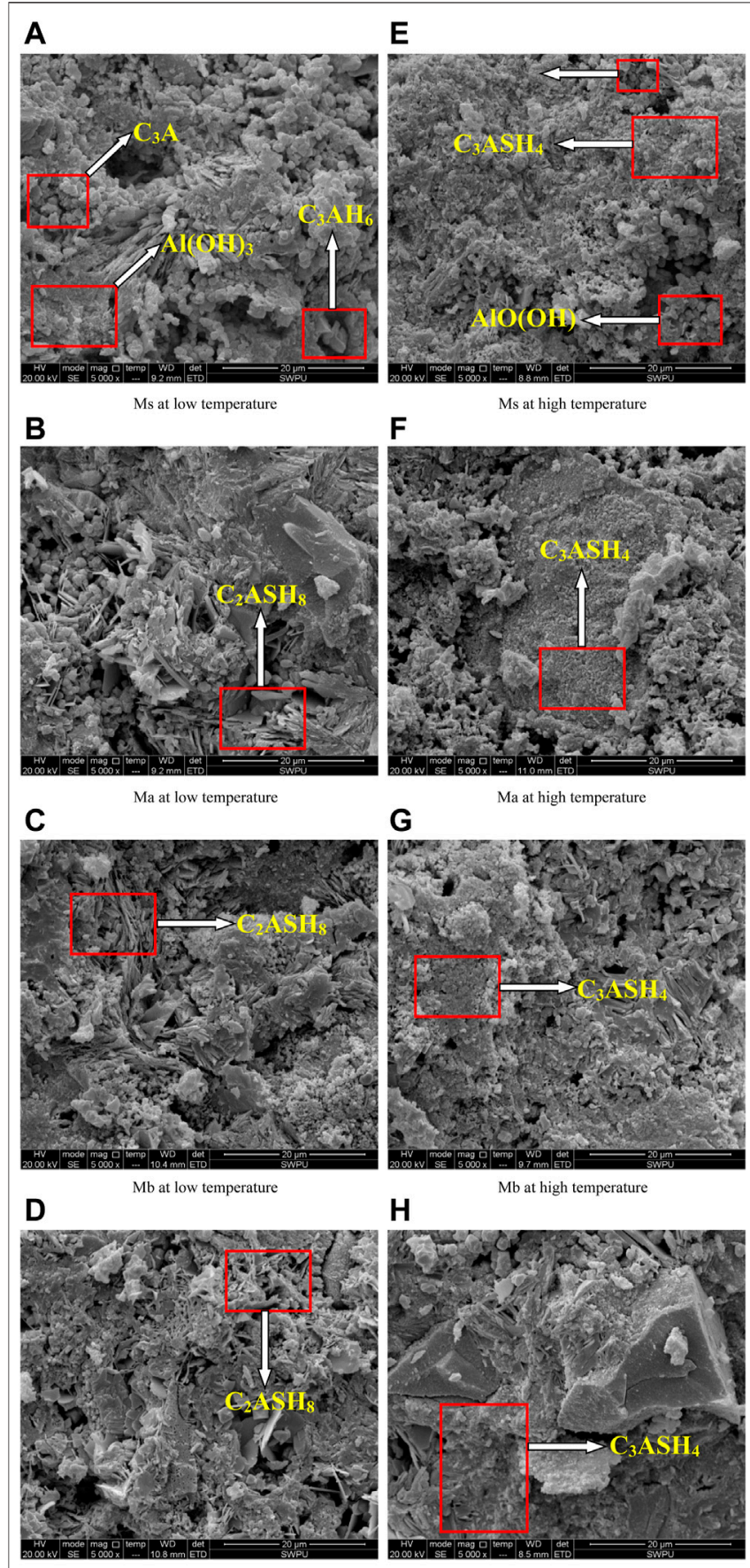

Mc at low temperature



H

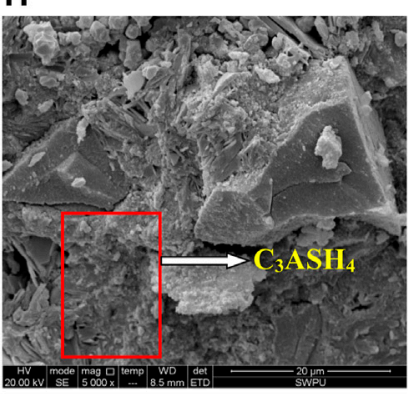

Mc at high temperature

FIGURE 4 | SEM pictures of CAC stone(5,000x). (A) Ms at low temperature. (B) Ma at low temperature. (C) Mb at low temperature. (D) Mc at low temperature. (E) Ms at high temperature. (F) Ma at high temperature. (G) $\mathrm{Mb}$ at high temperature. (H) Mc at high temperature.

CAC paste cured at $50^{\circ} \mathrm{C} \times 1.01 \mathrm{MPa}$ for 14 days. Figure $3 \mathrm{~B}$ shows the XRD pattern of CAC paste cured at $50^{\circ} \mathrm{C} \times 1.01 \mathrm{MPa}$ for 7 days, followed by curing at $315^{\circ} \mathrm{C} \times 20.7 \mathrm{MPa}$ for 7 days. Combining previous research results (Guo et al., 2020), under low curing temperature, the main hydrated phases of Ms were
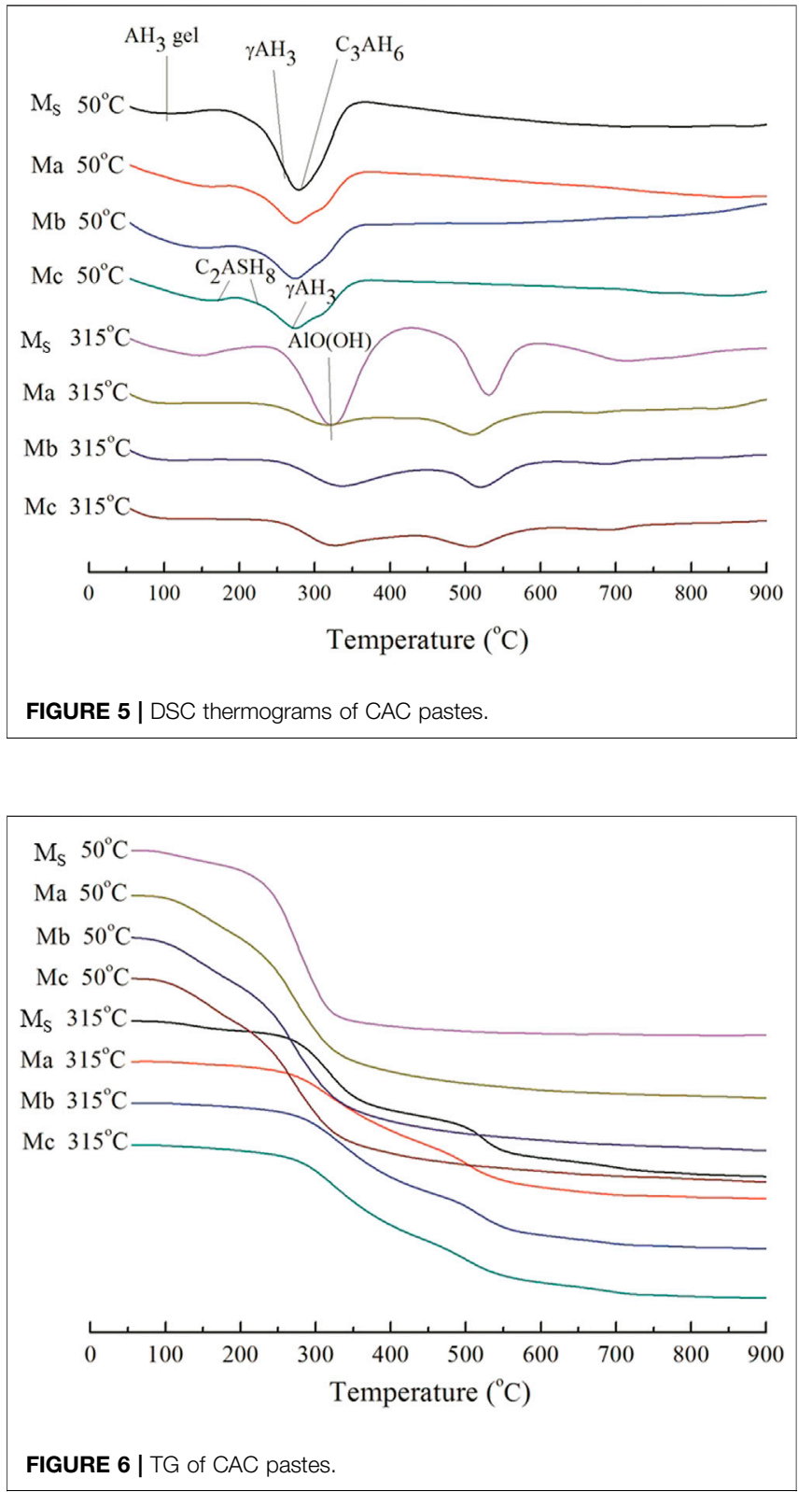

$\mathrm{C}_{3} \mathrm{AH}_{6}, \mathrm{C}_{2} \mathrm{AS}, \mathrm{Al}(\mathrm{OH})_{3}, \mathrm{C}_{3} \mathrm{~A}$, and $\mathrm{C}_{12} \mathrm{~A}_{7}$, and the main hydrated phases of $\mathrm{Ma}, \mathrm{Mb}$, and $\mathrm{Mc}$ were $\mathrm{C}_{2} \mathrm{ASH}_{8}, \mathrm{C}_{3} \mathrm{ASH}_{4}$, $\mathrm{Al}(\mathrm{OH})_{3}$, and $\mathrm{C}_{2} \mathrm{AS}$. Under high curing temperature, the main hydrated phases of $\mathrm{Ms}$ were $\mathrm{C}_{3} \mathrm{ASH}_{4}, \mathrm{AlO}(\mathrm{OH})$ and $\mathrm{C}_{3} \mathrm{~A}$. Meanwhile, the main hydrated phases of $\mathrm{Ma}, \mathrm{Mb}$, and $\mathrm{Mc}$ were $\mathrm{C}_{3} \mathrm{ASH}_{4}, \quad \mathrm{AlO}(\mathrm{OH})$, hydrated andradite $\left[\mathrm{Ca}_{3}\left(\mathrm{Fe}_{0.87} \mathrm{Al}_{0.13}\right)_{2}\left(\mathrm{SiO}_{4}\right)_{1.65}(\mathrm{OH})_{5.4}\right]$, and a small amount of $\mathrm{C}_{2} \mathrm{~S}$. As shown in Figure 3A, the CAC paste mixed with $\mathrm{FSa}$, $\mathrm{FSb}$, or FSc converted $\mathrm{C}_{3} \mathrm{AH}_{6}$ into $\mathrm{C}_{2} \mathrm{ASH}_{8}$. This conversion is the reason for the compressive strength of the CAC paste that was stably cured at low temperature. Mostafa et al. showed that the main function of $\mathrm{Na}_{2} \mathrm{SO}_{4}$ in CAC with blast furnace slag as an activator is to promote $\mathrm{C}_{2} \mathrm{ASH}_{8}$ generation. Comparing Figures $3 \mathbf{A}, \mathbf{B}$, the new products of $\mathrm{Ms}$ were $\mathrm{C}_{3} \mathrm{ASH}_{4}$ and $\mathrm{AlO}(\mathrm{OH})$ after curing at high temperature, and the new 
phases of $\mathrm{Ma}, \mathrm{Mb}$, and $\mathrm{Mc}$ were $\mathrm{C}_{3} \mathrm{ASH}_{4}, \mathrm{AlO}(\mathrm{OH})$, and andradite (hydrated). $\mathrm{C}_{3} \mathrm{AH}_{6}$ or $\mathrm{C}_{2} \mathrm{ASH}_{8}$ converted into $\mathrm{C}_{3} \mathrm{ASH}_{4}$, and $\mathrm{Al}(\mathrm{OH})_{3}$ converted into $\mathrm{AlO}(\mathrm{OH})$ at $315^{\circ} \mathrm{C} \times$ 20.7 $\mathrm{MPa}$. The strength of $\mathrm{Ma}, \mathrm{Mb}$, and $\mathrm{Mc}$ was reduced after high-temperature curing, but the reduction rate of the compressive strength was within 15\%, meeting the cementing requirements (Adolfsson et al., 2011; Li et al., 2014).

\section{Scanning Electron Microscopy}

The fracture surfaces of CAC paste were studied using SEM. The microstructures of hydrated $\mathrm{Ms}, \mathrm{Ma}, \mathrm{Mb}$, and Mc cured at $50^{\circ} \mathrm{C} \times$ $1.01 \mathrm{MPa}$ for 14 days, $50^{\circ} \mathrm{C} \times 1.01 \mathrm{MPa}$ for 7 days, and $315^{\circ} \mathrm{C} \times$ 20.7 MPa for another 7 days are shown in Figures $\mathbf{4 A - H}$. Figure $4 \mathrm{~A}$ shows that $\mathrm{Ms}$ generated cubic $\mathrm{C}_{3} \mathrm{AH}_{6}$, fine particles of $\mathrm{C}_{3} \mathrm{~A}$, and an amorphous $\mathrm{Al}(\mathrm{OH})_{3}$ gel when cured at low temperature (Ewais et al., 2009). This finding explains the increased quantity of holes and low compression strength of Ms. The micrographs of $\mathrm{Ma}, \mathrm{Mb}$, and $\mathrm{Mc}$ cured at $50^{\circ} \mathrm{C}$ (Figures 4B-D) indicate the presence of the thin flaky plate-like morphology of stratlingite $\left(\mathrm{C}_{2} \mathrm{ASH}_{8}\right)$ and small amounts of amorphous $\mathrm{Al}(\mathrm{OH})_{3}$ gel. This observation reveals that the microstructures of CAC mixed with blast furnace slag were more closed and compact. The micrographs of $\mathrm{Ms}, \mathrm{Ma}, \mathrm{Mb}$, and $\mathrm{Mc}$ curing at $315^{\circ} \mathrm{C}$ are shown in Figures $4 \mathrm{E}-\mathbf{H}$. Neat CAC paste and CAC with blast furnace slag mainly generated $\mathrm{C}_{3} \mathrm{ASH}_{4}$ and dehydrated $\mathrm{Al}(\mathrm{OH})_{3} \mathrm{AlO}(\mathrm{OH})$. With fewer fine particles, $\mathrm{C}_{3} \mathrm{~A}$ filled in the crystal gaps in the high-temperature environment where crystal structures are dense and well developed as well as have high crystallinity and good mechanical properties. Those are the root cause of the hightemperature resistance of CAC paste.

\section{Thermal Analysis}

The types of hydration products in CAC paste composites were investigated using differential scanning calorimetry (DSC) and thermos gravimetric (TG). DSC and TG thermographs of hydrated CAC paste (Ms, Ma, Mb, and $\mathrm{Mc}$ ) cured at low and high temperatures are shown in Figures 5, 6, respectively. The analysis of Figures 5, 6 revealed that Ms cured at low temperatures; $70-100^{\circ} \mathrm{C}$ and $278^{\circ} \mathrm{C}$, displayed an endothermic peak because of $\mathrm{Al}(\mathrm{OH})_{3}$. Given that $\mathrm{Al}(\mathrm{OH})_{3}$ is a polycrystalline (Mac et al., 2014), a mass loss of approximately 5.4\% occurred. At $270-350^{\circ} \mathrm{C}$, the endothermic peak was due to $\mathrm{C}_{3} \mathrm{AH}_{6}$, and the mass loss was approximately $19.8 \%$. For $\mathrm{Ma}, \mathrm{Mb}$, and $\mathrm{Mc}$ at 163 and $210^{\circ} \mathrm{C}$, the peak was mainly due to $\mathrm{C}_{2} \mathrm{ASH}_{8}$ (Sitnikov et al., 2009), leading to a mass loss of approximately $16.4,16.4$, and $16.1 \%$, respectively. Heikal et al. found that CAC mixed with $25 \%$ air-cooled or water-cooled blast furnace slag can reduce $\mathrm{C}_{3} \mathrm{AH}_{6}$ formation by $54.6 \%$ when cured at $40^{\circ} \mathrm{C}$ to ensure the strength of the generated CAC paste. When cured at high temperature and high pressure, the positions of the endothermic peak of Ms, Ma,
$\mathrm{Mb}$, and $\mathrm{Mc}$ were 300 and $500^{\circ} \mathrm{C}$, respectively. This result shows the location of the endothermic peak at higher temperatures. The endothermic peak of Ms was prominent and absorbed more heat, whereas the endothermic peaks of $\mathrm{Ma}, \mathrm{Mb}$, and $\mathrm{Mc}$ were relatively small. Compared with the TG curve for curing at low and high temperatures, the mass loss rates decreased with an increase in curing temperature. Thus, blast furnace slag added to CAC can lead to more stable hydration products at high temperature and can increase high-temperature resistance performance. XRD results showed that the endothermic peak at $325^{\circ} \mathrm{C}$ may be attributed to $\mathrm{AlO}(\mathrm{OH})$, which causes a loss of crystallized water (Ptáček et al., 2010).

\section{CONCLUSION}

1) The reaction of blast furnace slag and CAC can generate $\mathrm{C}_{2} \mathrm{ASH}_{8}$, which can effectively improve its low temperature sensitivity;

2) The compressive strength and permeability resistance of $\mathrm{Mc}$ increased by 74.2 and $77.5 \%$, respectively, compared with Ms.

3) The main reason for the high temperature resistance of CAC is $\mathrm{C}_{3} \mathrm{ASH}_{4}$ and $\mathrm{AlO}(\mathrm{OH})$ produced by hydration under high temperature curing; The addition of blast furnace slag can make the high temperature performance of CAC more stable.

\section{DATA AVAILABILITY STATEMENT}

The original contributions presented in the study are included in the article/Supplementary material, further inquiries can be directed to the corresponding authors.

\section{AUTHOR CONTRIBUTIONS}

$\mathrm{WZ}$ is responsible for the overall idea of the article and writing the paper; LH, QX, WG, and XX are responsible for providing experimental materials and conducting specific experiments; $\mathrm{CX}$ and NX are responsible for data analysis and article verification.

\section{ACKNOWLEDGMENTS}

The authors appreciate the support of the CNOOC project ""Feasibility Study on Low Permeability Development of Bozhong 25-1S Oilfield 5 Well Block and Sha 3 Member"" (No. 2021FS-02). The authors would also like to thank the Advanced Cementing Materials Research Center of SWPU for their kind assistance with the experiments. 


\section{REFERENCES}

Abolhasani, A., Nazarpour, H., and Dehestani, M. (2021). Effects of Silicate Impurities on Fracture Behavior and Microstructure of Calcium Aluminate Cement concrete. Eng. Fracture Mech. 242, 107446. doi:10.1016/j.engfracmech.2020.107446

Adolfsson, D., Robinson, R., Engström, F., and Björkman, B. (2011). Influence of Mineralogy on the Hydraulic Properties of Ladle Slag. Cement Concrete Res. 41, 865-871. doi:10.1016/j.cemconres.2011.04.003

Amin, M. S., Habib, A. O., and Abo-El-Enein, S. A. (2012). Hydrothermal Characteristics of High-Slag Cement Pastes Made with and without Silica Sand. Adv. Cement Res. 24, 23-31. doi:10.1680/adcr.2012.24.1.23

Antonovič, V., Kerienė, J., Boris, R., and Aleknevičius, M. (2013). The Effect of Temperature on the Formation of the Hydrated Calcium Aluminate Cement Structure. Proced. Eng. 57, 99-106. doi:10.1016/j.proeng.2013.04.015

Chai, M., Yang, M., and Chen, Z. (2022). Analytical and Numerical Study of thermal and Solvent-Based Gravity Drainage for Heavy Oil Recovery. J. Pet. Sci. Eng. 208, 109214. doi:10.1016/j.petrol.2021.109214

Cheng, X., Dong, Q., Ma, Y., Zhang, C., Gao, X., Yu, Y., et al. (2019). Mechanical and thermal Properties of Aluminate Cement Paste with Blast Furnace Slag at High Temperatures. Construction Building Mater. 228, 116747. doi:10.1016/ j.conbuildmat.2019.116747

Ding, B., Dong, M., Chen, Z., and Kantzas, A. (2021). Enhanced Oil Recovery by Emulsion Injection in Heterogeneous Heavy Oil Reservoirs: Experiments, Modeling and Reservoir Simulation. J. Pet. Sci. Eng. 2021, 109882. doi:10.1016/j.petrol.2021.109882

Ewais, E. M. M., Khalil, N. M., Amin, M. S., Ahmed, Y. M. Z., and Barakat, M. A. (2009). Utilization of Aluminum Sludge and Aluminum Slag (Dross) for the Manufacture of Calcium Aluminate Cement. Ceramics Int. 35, 3381-3388. doi:10.1016/j.ceramint.2009.06.008

Fentiman, C. H., and Science, C. (2020). "The Effect of Curing Conditions on the Hydration and Strength Development of Fondu Slag Calcium Aluminate Cements," in Proceedings of the International Symposium Held at Queen Mary and Westfield. Editor R. J. Mangabhai (London; New York: E. \& F.N. Spon).

Goberis, S., and Antonovich, V. (2004). Influence of Sodium Silicate Amount on the Setting Time and EXO Temperature of a Complex Binder Consisting of High-Aluminate Cement, Liquid Glass and Metallurgical Slag. Cement Concrete Res. 34, 1939-1941. doi:10.1016/j.cemconres.2004.01.004

Guo, C., Wang, E., Hou, X., Chen, J., Zhang, W., Ye, J., et al. (2020). Characterization and Mechanism of Early Hydration of Calcium Aluminate Cement with Anatase-TiO2 Nanospheres Additive. Construction Building Mater. 261, 119922. doi:10.1016/j.conbuildmat.2020.119922

Heikal, M., Morsy, M. S., and Radwan, M. M. (2005). Electrical Conductivity and Phase Composition of Calcium Aluminate Cement Containing Air-Cooled and Water-Cooled Slag at 20, 40 and $60{ }^{\circ}$ C. Cement Concrete Res. 35, 1438-1446. doi:10.1016/j.cemconres.2004.09.027

Huang, J., Li, W., Huang, D., Wang, L., Chen, E., Wu, C., et al. (2021). Fractal Analysis on Pore Structure and Hydration of Magnesium Oxysulfate Cements by First Principle, Thermodynamic and Microstructure-Based Methods. Fractal Fract 5, 164. doi:10.3390/fractalfract5040164

Idrees, M., Ekincioglu, O., and Sonyal, M. S. (2021). Hydration Behavior of Calcium Aluminate Cement Mortars with mineral Admixtures at Different Curing Temperatures. Construction Building Mater. 285, 122839 . doi:10.1016/ j.conbuildmat.2021.122839

Kar, A., Ray, I., Unnikrishnan, A., and Davalos, J. F. (2012). Estimation of C-S-H and Calcium Hydroxide for Cement Pastes Containing Slag and Silica Fume. Construction Building Mater. 30, 505-515. doi:10.1016/j.conbuildmat.2011.12.029

Kırca, Ö., Özgür Yaman, İ., and Tokyay, M. (2013). Compressive Strength Development of Calcium Aluminate Cement-GGBFS Blends. Cement and Concrete Composites 35, 163-170. doi:10.1016/j.cemconcomp.2012.08.016

Li, Z., Wang, Y., Cheng, X., and Guo, X. (2014). The Slag Influence on High Temperature Resistance of Aluminophosphate Cementfor Heavy Oil Thermal Recovery. High Temp. Mater. Process. 33, 325-328. doi:10.1515/htmp-20130064

Mac, F., Diego, O., Hollman, N., Energy, P. R., Javier, U., and Alberto, G. (2014). "Long-Term Calcium Phosphate Cement for In-Situ Combustion Project Synchronized Thermal Additional Recovery (STAR) Project," in SPE Heavy Oil Conference (Alberta, Canada: SPE), 1-10.
Mostafa, N. Y., Zaki, Z. I., and Abd Elkader, O. H. (2012). Chemical Activation of Calcium Aluminate Cement Composites Cured at Elevated Temperature. Cement and Concrete Composites 34, 1187-1193. doi:10.1016/j.cemconcomp.2012.08.002

Nabih, A., and Chalaturnyk, R. (2014). Stochastic Life Cycle Approach to Assess Wellbore Integrity for CO2 Geological Storage. Soc. Pet. Eng. - SPE Heavy Oil Conf. Can. 3, 2071-2090. doi:10.2118/170183-ms

Pacewska, B., Nowacka, M., Aleknevičius, M., and Antonovič, V. (2013). Early Hydration of Calcium Aluminate Cement Blended with Spent FCC Catalyst at Two Temperatures. Proced. Eng. 57, 844-850. doi:10.1016/j.proeng.2013.04.107

Pang, Z., Lyu, X., Zhang, F., Wu, T., Gao, Z., Geng, Z., et al. (2018). The Macroscopic and Microscopic Analysis on the Performance of Steam Foams during thermal Recovery in Heavy Oil Reservoirs. Fuel 233, 166-176. doi:10.1016/j.fuel.2018.06.048

Ptáček, P., Kubátová, D., Havlica, J., Brandštetr, J., Šoukal, F., and Opravil, T. (2010). Isothermal Kinetic Analysis of the thermal Decomposition of Kaolinite: The Thermogravimetric Study. Thermochim. Acta 501, 24-29. doi:10.1016/ j.tca.2009.12.018

Roig-Flores, M., Lucio-Martin, T., Alonso, M. C., and Guerreiro, L. (2021). Evolution of Thermo-Mechanical Properties of concrete with Calcium Aluminate Cement and Special Aggregates for Energy Storage. Cement Concrete Res. 141, 106323. doi:10.1016/j.cemconres.2020.106323

Sakai, E., Sugiyama, T., Saito, T., and Daimon, M. (2010). Mechanical Properties and Micro-structures of Calcium Aluminate Based Ultra High Strength Cement. Cement Concrete Res. 40, 966-970. doi:10.1016/j.cemconres.2010.01.001

Salehpour, A. G., Pershikova, E., Chougnet-Sirapian, A., Taoutaou, S., and Adiningtyas, D. A. (2014). Novel Steam-Resilient Cement System for Long-Term Steam Injection Well Integrity: Case Study of a Steamflooded Field in Indonesia. Soc. Pet. Eng. - SPE Heavy Oil Conf. Can. 1, 525-533. doi:10.2118/170048-ms

Sitnikov, P. A., Belykh, A. G., Fedoseev, M. S., Vaseneva, I. I., and Kuchin, A. V. (2009). Study of Chemical Processes in the Modification of Epoxide Polymers by Aluminum Oxide. Russ. J. Gen. Chem. 79, 2594-2598. doi:10.1134/S1070363209120068

Tseng, W. J., and Nian, J. (2004). Effect of Ammonium Polyacrylate on Rheology of Anatase TiO2 Nanoparticles Dispersed in Silicon Alkoxide Sols. Ceramics Int. 30, 2305-2311. doi:10.1016/j.ceramint.2004.01.011

Ukrainczyk, N., and Matusinović, T. (2010). Thermal Properties of Hydrating Calcium Aluminate Cement Pastes. Cement Concrete Res. 40, 128-136. doi:10.1016/j.cemconres.2009.09.005

Walker, W. A. (1962). Cementing Compositions for Thermal Recovery Wells. J. Pet. Technol. 14, 139-142. doi:10.2118/131-pa

Wang, L., Li, G., Li, X., Guo, F., Tang, S., Lu, X., et al. (2021). Influence of Reactivity and Dosage of $\mathrm{MgO}$ Expansive Agent on Shrinkage and Crack Resistance of Face Slab concrete. Cement and Concrete Composites 2021, 104333. doi:10.1016/ j.cemconcomp.2021.104333

Wang, L., Luo, R., Zhang, W., Jin, M., and Tang, S. (2021). Effects of Fineness and Content of Phosphorus Slag on Cement Hydration, Permeability, Pore Structure and Fractal Dimension of concrete. Fractals 29, 2140004. doi:10.1142/S0218348X21400041

Conflict of Interest: WZ, WG, and XX were employed by the company CNOOC Research Institute Co., Ltd. LH was employed by the company PetroChina Southwest Oil and Gas Ffield Company. QX was employed by the company CNPC Chuanqing Drilling Engineering Company Limited.

The remaining author declares that the research was conducted in the absence of any commercial or financial relationships that could be construed as a potential conflict of interest.

Publisher's Note: All claims expressed in this article are solely those of the authors and do not necessarily represent those of their affiliated organizations, or those of the publisher, the editors and the reviewers. Any product that may be evaluated in this article, or claim that may be made by its manufacturer, is not guaranteed or endorsed by the publisher.

Copyright (c) 2022 Zhiqiang, Hengie, Xiong, Guangai, Xuesong, Xiaowei and Xiucheng. This is an open-access article distributed under the terms of the Creative Commons Attribution License (CC BY). The use, distribution or reproduction in other forums is permitted, provided the original author(s) and the copyright owner(s) are credited and that the original publication in this journal is cited, in accordance with accepted academic practice. No use, distribution or reproduction is permitted which does not comply with these terms. 